\title{
Letter to the Editor: Methicillin-Resistant Staphylococcus epidermidis in Organic Milk Production
}

\author{
C. Walther and V. Perreten ${ }^{1}$ \\ Institute of Veterinary Bacteriology, University of Berne, $\mathrm{CH}-3001$ Bern, Switzerland
}

A dairy cow from a farm for organic milk production, where the use of antibiotics is restricted, was diagnosed twice within 2 mo with subclinical mastitis caused by methicillin-resistant Staphylococcus epidermidis. The strains also displayed resistance to chloramphenicol and harbored streptomycin- and trimethoprim-resistance genes that remained silent in vitro. The second isolate contained an additional aminoglycoside-resistance gene indicating the potential acquisition of resistance by horizontal gene transfer.

The increasing demand for organic products has led to new regulations in Swiss agriculture (Swiss Federal Council, 1997). In organic dairy farming, the prophylactic use of antibiotics is not permitted. In cases of subclinical mastitis, antibiotics can only be given if previous homeopathic treatments have failed and if antibiotic resistance profiles of isolated pathogens have been determined. Despite these preventative measures, the frequency of antibiotic resistance in mastitis pathogens from organic farms was not found to be different from those of conventional farms (Roesch et al., 2006). Sixteen and $18 \%$ of the cows from organic and conventional farms, respectively, harbored staphylococci displaying resistance to oxacillin, the indicator antibiotic used to predict the presence of the methicillin-resistance gene $(m e c A)$ in staphylococci. This gene, which mediates resistance to all $\beta$-lactam antibiotics, was only detected in isolates from organic farms.

Two methicillin-resistant Staph. epidermidis strains (BL133 and BL302) were isolated 2 mo apart from the same quarter of a cow, on an organic farm, suffering from subclinical mastitis. Both strains had identical SmaI-pulsed-field gel electrophoresis patterns of chromosomal DNA. They displayed resistance to oxacillin (MIC: $1 \mu \mathrm{g} / \mathrm{mL}$; mecA) and chloramphenicol (MIC: 64 $\left.\mu \mathrm{g} / \mathrm{mL} ; c a t_{\mathrm{pC221}}\right)$, and harbored the trimethoprim-resistance gene, $d f r(\mathrm{~A})$, the streptothricin acetyltransferase gene, sat4, and the streptomycin nucleotydyltransfer-

Received July 25, 2007.

Accepted September 4, 2007.

${ }^{1}$ Corresponding author: vincent.perreten@vbi.unibe.ch ase gene, ant(6)-Ia, as determined by broth dilution and microarray (Perreten et al., 2005; CLSI, 2006). The second strain isolated, BL302, had an additional aminoglycoside phosphotransferase gene, aph $\left(3^{\prime}\right)$-III, indicating the potential acquisition of resistance by horizontal gene transfer. Both strains however, remained susceptible to trimethoprim (MIC: $\leq 0.5 \mu \mathrm{g} / \mathrm{mL}$ ) and to the aminoglycosides streptomycin (MIC: $4 \mu \mathrm{g} / \mathrm{mL}$ ), neomycin (MIC: $\leq 1 \mu \mathrm{g} / \mathrm{mL}$ ), and kanamycin (MIC: $2 \mu \mathrm{g} / \mathrm{mL}$ ) in vitro.

This finding shows that food-producing animals kept on organic farms may harbor multidrug-resistant staphylococci despite the limited use of antibiotics. Strict hygiene standards should be applied to reduce the level of bacterial contamination of cows on the farm and the spread of bacteria with pathogenic potential to humans through the food chain. Organic milk destined for raw milk cheese production, as well as cheese made thereof, should be subject to careful bacteriological analysis and should not contain bacteria harboring transferable antibiotic resistance genes.

The presence of methicillin-resistant Staph. epidermidis in organic food-producing animals should convince farmers, veterinarians, public health authorities, cheese producers, and cheese retailers to take adequate measures to limit the spread of antibiotic-resistant bacteria to humans via the food chain.

\section{REFERENCES}

CLSI (Clinical and Laboratory Standards Institute). 2006. Methods for dilution antimicrobial susceptibility tests for bacteria that grow aerobically. Vol. 26, No. 2. 7th ed. Approved standard M7A7. Clinical and Laboratory Standards Institute, Wayne, PA.

Perreten, V., L. Vorlet-Fawer, P. Slickers, R. Ehricht, P. Kuhnert, and J. Frey. 2005. Microarray-based detection of 90 antibiotic resistance genes of gram-positive bacteria. J. Clin. Microbiol. 43:2291-2302.

Roesch, M., V. Perreten, M. G. Doherr, W. Schaeren, M. Schällibaum, and J. W. Blum. 2006. Comparison of antibiotic resistance of udder pathogens in dairy cows kept on organic and on conventional farms. J. Dairy Sci. 89:989-997.

Swiss Federal Council. 1997. Ordinance on organic farming and the labelling of organically produced products and foodstuffs, SR 910.18. Federal Authorities of the Swiss Confederation, Bern, Switzerland. 